\title{
ESTIMATION AND EFFECTS OF INTERNAL ACCUMULATION ON FIVE GLACIERS IN ALASKA
}

\author{
by
}

\author{
D. C. Trabant and L. R. mayo
}

US Geological Survey, Cold Regions Hydrology Project Office, 101 12th Avenue, Box 11, Fairbanks, Alaska 99701

\begin{abstract}
Estimates of internal accumulation for five Alaskan glaciers in different climates suggests that internal accumulation occurs in glaciers throughout Alaska. A method of estimating the quantity of internal accumulation is based on the annual minimum temperature of the snow-firn interface. The consistency of the estimates suggests that valid approximations of internal accumulation can be made over large areas. The estimates have not been confirmed by measurements of mass change, but are believed to be accurate within 10 percent. Point balance quantities of internal accumulation range from $0.65 \mathrm{~m} \mathrm{a}^{-1}$, which is $64 \%$ of the annual accumulation on McCall Glacier, to $0.12 \mathrm{~m}$ $\mathrm{a}^{-1}, 7 \%$ of the annual accumulation on Wolverine Glacier. The amount of internal accumulation decreases rapidly from north to south in Alaska; however it should be expected worldwide where sub-freezing, porous firn is invaded by water.

Internal accumulation occurs in temperate glaciers in strongly maritime climates as well as glaciers in cold continental climates where it delays the onset of runoff, accelerates the process of converting snow into glacier ice, and explains the occurrence of temperate glaciers in permaf rost areas.
\end{abstract}

\section{INTRODUCTION}

Internal accumulation is an of ten-ignored, usually small, glacier mass balance quantity that affects the thermal regime and runoff characteristics of glaciers. There are two components of internal accumulation; (1) water that percolates into cold firn and freezes immediately, and (2) water that is trapped as capillary water which may or may not freeze at a later time. The released latent heat of fusion raises the temperature of the $f$ irn in the accumulation area. Both freezing and capillary retention of water delay the onset of runoff and reduce the total runoff

The annual internal accumulation balance term, $b_{a}(k)$, is defined as the water equivalent added to "old firn and ice" during one year. It is an addition to the balance terminology developed by Mayo and others (1972), in which the material above the most recently buried summer surface is termed snow, b(s); the material below it is referred to as "old firn and ice", b(i); and the subscript "a" denotes a fixed-date, annual balance term. Internal accumulation includes the relatively small quantities of ice added to the ablation area as crevasse wall coatings but excludes redistribution of mass within snow.

Internal accumulation has been widely recognized (eg Hughes and Seligman 1939; Ahlmann 1948; Benson 1962; and Müller 1962), but has not been measured or estimated of ten in balance studies because it has been considered to be insignificant. When it has been considered, usually only the component responsible for warming the firn is evaluated (eg Paterson 1981).

Measurement of internal accumulation by repeated density-depth profiles is frustrated by the complex three-dimesional network of ice glands, lenses, and layers that characterize its occurrence (Wendler and others
1975); and by the added uncertainty of estimating the amount of water in such firn units. An easier method was required before internal accumulation was routinely evaluated at long-term glacier mass balance monitoring sites. It is important because our estimates for the McCall Glacier (Brooks Range, $69^{\circ} \mathrm{N}$ ), Black Rapids Glacier (Alaska Range, $63^{\circ} \mathrm{N}$ ), Gulkana Glacier (Alaska Range, $63^{\circ} \mathrm{N}$ ), Columbia Glacier (Chugach Mts., $61^{\circ} \mathrm{N}$ ), and Wolverine Glacier (Kenai Mts., $60^{\circ} \mathrm{N}$ ) (Figure 1) indicate that internal accumulation occurs throughout

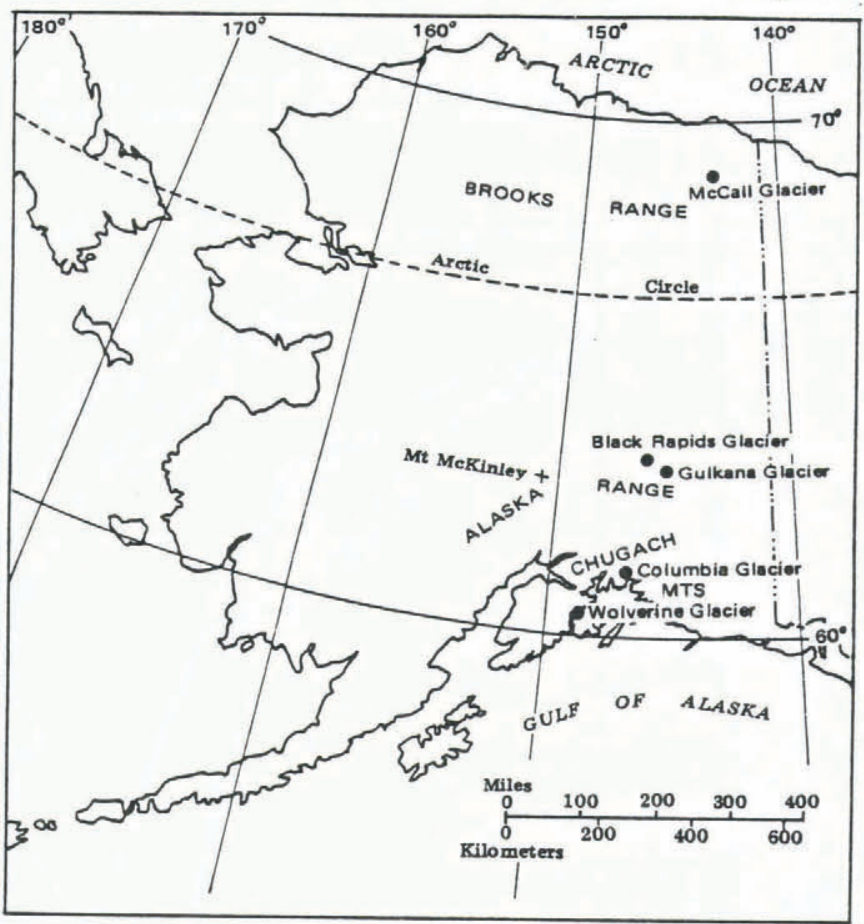

Fig.1. Alaska location map.

Alaska; produces significant mass balance, thermal, and runoff effects; and is probably a significant process occurring on glaciers throughout the world.

We propose a simple, indirect method of estimating internal accumulation. Earlier work was done by Bazhev (1973) who successfully measured internal accumulation and developed an indirect method of estimating its magnitude. Our work extends that of Bazhev.

\section{ESTIMATING INTERNAL ACCUMULATION}

The potential for the two components of internal accumulation is created each time cold firn is invaded by percolating water. The downward flux of water penetrates the underlying summer surface or snow-firn interface, $\mathrm{H}_{\mathrm{sf}}$, and simultaneously warms the firn by freezing and fills the capillary water deficit in the firn. A single such "cycle" of firn warming and wetting is most common in Alaska each year. 
The quantity of each component of internal accumulation may be estimated by analyzing the effect that percolating water has on the heat balance of the firn. No internal accumulation is formed when firn temperatures increases are due to conduction alone; because no mass is added to the firn.

The firn-warming component, $\mathrm{b}(\mathrm{k})$, occurs when water percolates into cold firn and freezes; where (k) specifies internal accumulation in the balance term. The easily-measured firn temperature increase is related directly to the latent heat released, providing a calorimetric like measure of the water frozen in the firn. The natural calorimeter is closed above by the isothermal snow. The firn warming component is the most widely recognized part (eg Liestøl 1967; Messel 1971), and can be expressed as:

$$
b_{w}(k)=\int_{H_{s f}}^{H_{w}} \rho_{f} C \Delta T / L d h,
$$

where $\rho_{f}$ is the old firn density at depth $h, C$ is the specific heat of ice, $\Delta \mathrm{T}$ is the temperature increase in degrees Celsius at depth $h, L$ is the latent heat of fusion of ice, $\mathrm{H}_{\mathrm{sf}}$ is the snow-firn interface depth, and $\mathrm{H}_{\mathrm{w}}$ is the depth of seasonal warming.

The capillary component, $\mathrm{b}(\mathrm{k})$, is the water held by capillary retention in the firn. This has generally not been recognized in mass balance studies, is usually the larger of the two components, and may be expressed as:

$$
b_{c}(k)=\int_{H_{s f}}^{H_{c}} S_{w i}\left[1-\left(\rho_{f} / \rho_{i}\right)\right] d h,
$$

where $\mathrm{S}_{w i}$ is "the irreducible water saturation due to capillary retention (Colbeck 1974), which is about $7 \%$ of the pore volume, $\rho_{f}$ is the old firn density at depth $h$, $\rho_{i}$ is the density of ice, and $H_{c}$ is the maximum depth to which firn is wetted. On temperate glaciers, $\mathbf{H}_{w}$ and $\mathrm{H}_{\mathrm{c}}$ are equal. On sub-temperate glaciers, the depth to which the firn is wetted $\left(\mathrm{H}_{\mathrm{c}}\right)$ is less than the depth of seasonal warming $\left(\mathrm{H}_{\mathrm{w}}\right)$

Equation 2 can also be used to calculate the amount of capillary water converted to ice by the advance of the subsequent winter cold wave; by substituting the maximum depth of winter freezing for $\mathrm{H}_{\mathrm{c}}$.

Annual internal accumulation is the sum of the two components:

$$
b_{a}(k)=b_{w}(k)+b_{c}(k)
$$

The method we propose for estimating $b_{a}(k)$ is to derive a general relation between the minimum snow-firn interface temperature and the amount of internal accumulation developed by using empirical temperature and firn density functions in Equation 3.

Firn temperature measurements at Gulkana, Black Rapids (Harrison and others 1975) and McCall Glaciers (Trabant and others 1975) (Figure 2a) are the basis for the generalized set of firn temperatures for glaciers in Alaska (Figure 2b). The firn temperature data (Figure 2a) suggest that the firn on the three glaciers has similar thermal properties, that a generalization is possible, and that the minimum snow-firn interface temperature is a good indicator of the firn temperature distribution at the time percolating water first reaches the interface. Warming at the top of the firn (Figure $2 \mathrm{~b})$ is due to heat conducted from the overlying snow, and is not considered to be part of $b_{w}(k)$ (Equation 1).

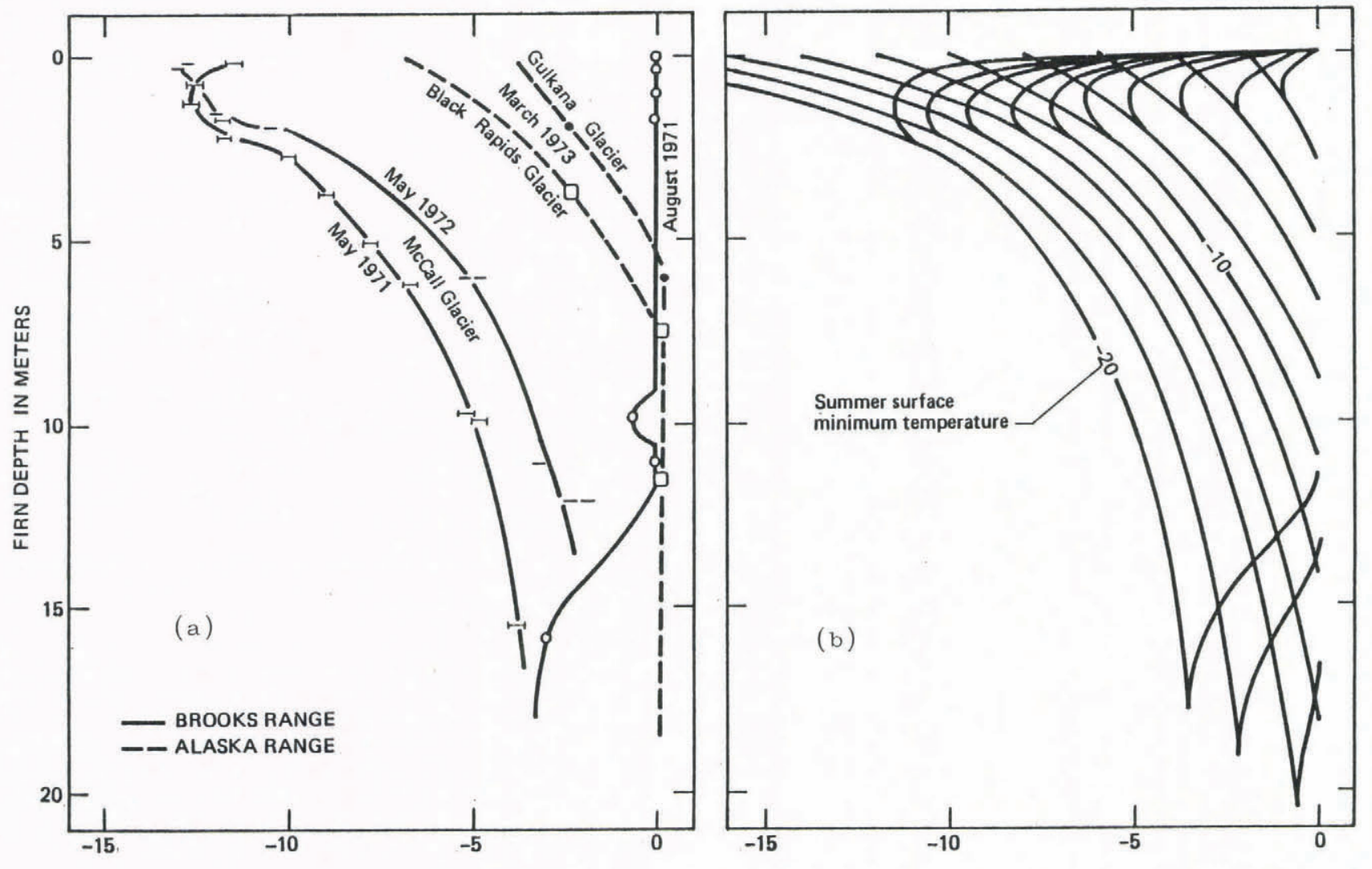

TEMPERATURE IN DEGREES CELSIUS

Fig.2. (a) Firn temperature data from $2400 \mathrm{~m}$ altitude on McCall Glacier from Trabant and others (1975), $1900 \mathrm{~m}$ altitude on Black Rapids Glacier from Harrison and others (1975), and $1800 \mathrm{~m}$ altitude on Gulkana Glacier. (b) Generalized firn temperature profiles for temperate and sub-temperate glaciers in central and northern Alaska, showing the relation between the snow-firn interface minimum temperature profiles and the assumed temperature profiles at the time percolating water reaches the snow-firn interface. 


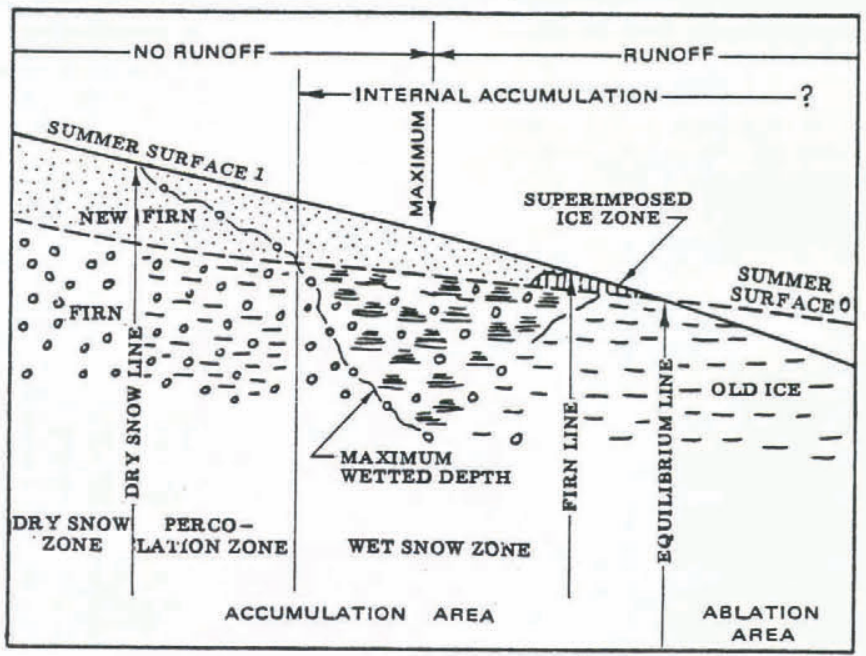

Fig.3. Schematic glacier zones, based on Benson (1959) and Muller (1962). This figure shows the conditions after the end of the ablation season.

We assume that the permeable firn of all wet snow zones (Figure 3) may be represented by a linear depth-density function from $0.53 \mathrm{Mg} \mathrm{m}^{-3}$ at the top of the firn to $0.7 \mathrm{Mg} \mathrm{m}^{-3}$ at $20 \mathrm{~m}$ depth. This assumption makes Equation 2 linear with depth and sensitive to the correct determination of $\mathrm{H}_{\mathrm{c}}$.

The general relation between the minimum snow-firn interface temperature and internal accumulation (Figure 4) was derived by successive evaluations of Equation 3 using the generalized temperature profiles (Figure $2 \mathrm{~b}$ ) and the linear density distribution function. This relation shows that the capillary component, $b_{c}(k)$, is larger than the firn warming component, $b_{w}(k)$ for all interface temperatures above $-17^{\circ} \mathrm{C}$

The magnitude of internal accumulation was verified by work on McCall Glacier (Wendler and others 1975) and in Russia (Bazhev 1973). Applying Equation 3 to the data presented by Bazhev (1973) produces results within $10 \%$ of his measurements, after adjustments for the difference in definitions. Better estimates could be

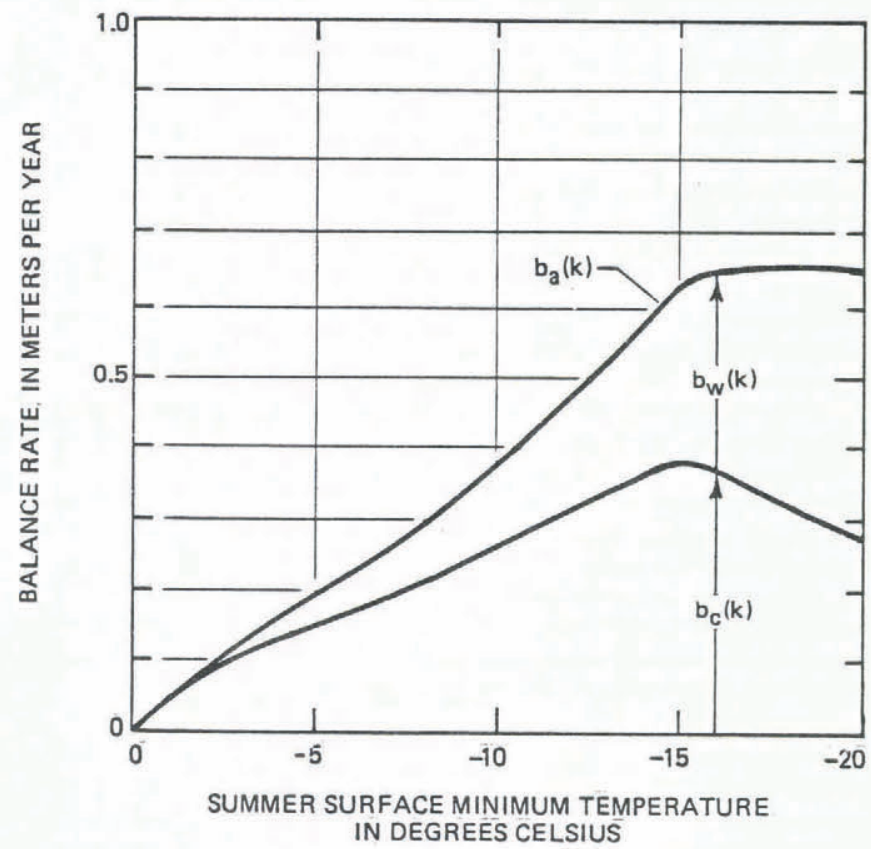

Fig.4. Graph of estimated internal accumulation as a function of the minimum snow-firn interface temperature showing the relative contribution of the firn-warming component $b_{w}(k)$ and the capillary component $b_{c}(k)$. made with improved understanding of the distribution of firn densities and temperatures within glaciers. The estimates of internal accumulation on glaciers in Alaska are judged to be within $10 \%$ where snow-firn interface data are available. The error in mass balance calculations due to omitting internal accumulation from consideration is much larger than the error in estimating internal accumulation.

\section{EFFECTS ON MASS BALANCE}

On the five glaciers where estimates of $b_{s}(k)$ have been made, the effect on mass balance is most pronounced at $2400 \mathrm{~m}$ in the accumulation area of McCall Glacier, where firn temperatures and annual precipitation are the lowest of all the sites. In 1971, 0.65 $\mathrm{m}$ internal accumulation was formed at a point where the annual accumulation was $1.01 \mathrm{~m}$. For that year, more than $60 \%$ of the annual accumulation was $b_{a}(k)$. This internal accumulation was composed of nearly equal parts $b_{c}(k)$ and $b_{w}(k)$ and was distributed through approximately 8 previous firn accumulation increments.

In the Alaska Range, firn temperatures measured in 1973 (Harrison and others 1975) and 1974 were used to estimate internal accumulation at Black Rapids and Gulkana Glaciers. In 1974 at 2020 m altitude on Black Rapids, $0.26 \mathrm{~m}$ of internal accumulation was $21 \%$ of the $1.26 \mathrm{~m}$ annual accumulation; and at $1840 \mathrm{~m}$ on nearby Gulkana Glacier $0.15 \mathrm{~m}$ of internal accumulation was $12 \%$ of the $1.25 \mathrm{~m}$ annual accumulation. Snow-firn interface temperatures in the area of maximum internal accumulation on Gulkana Glacier range from -4 to $-7^{\circ} \mathrm{C}$ (Harrison and others 1975); therefore, more than $80 \%$ of the internal accumulation is $b_{c}(k)$ (Figure 4), the part that has most of ten been ignored.

On Wolverine Glacier, measured snow-firn interface temperatures since 1967 are used to estimate internal accumulation. At $1300 \mathrm{~m}$ altitude, where internal accumulation is maximum for this glacier, an average of $0.12 \mathrm{~m}$ of internal accumulation is formed under an average of $2.1 \mathrm{~m}$ water equivalent of new firn each year; therefore $5 \%$ of the total annual accumulation is $b_{a}(k)$ of which more than $85 \%$ is $b_{c}(k)$.

Columbia Glacier extends well above the point of maximum internal accumulation into the percolation zon (Figure 3). The annual snow increment at $2700 \mathrm{~m}$ was cored in the fall of 1978 and was wetted only half way through; therefore no $b_{a}(k)$ formed there. The maximum internal accumulation was estimated to be $0.15 \mathrm{~m}$ at 2100 altitude (Figure 6) where the annual surface balance was $2.6 \mathrm{~m}$; therefore, $\mathrm{b}_{\mathrm{a}}(\mathrm{k})$ was $5 \%$ of the 1978 annual accumulation. Here, as on Wolverine Glacier, the largest part, $85 \%$, of the $b_{a}(k)$ is due to capillary
retention $b_{c}(k)$.

\section{EFFECTS ON THERMAL REGIME}

If englacial temperatures were due to conduction and ice advection alone, most glaciers would be colder than the mean annual air temperature $\left(\overline{\mathrm{T}}_{\mathrm{a}}\right)$. Glaciers in Alaska are, however, generally much warmer than $\overline{\mathrm{T}}_{\text {. }}$ The thermal anomaly is proportional to the latent heat released by internal accumulation which causes firn in the wet snow zone to be surprisingly warm.

The effect can be demonstrated by comparing the $\overline{\mathrm{T}}_{\mathrm{a}}$ with glacier temperature data from a depth of $10 \mathrm{~m}$ where the annual cycle is usually less than one degree. On McCall Glacier the temperature of the old firn is as much as $13^{\circ} \mathrm{C}$ higher than the $\overline{\mathrm{T}}_{\mathrm{a}}$ (Trabant and others 1975). This temperature deviation occurs at about 2300 $\mathrm{m}$ altitude, where the internal accumulation $\left(0.65 \mathrm{~m} \mathrm{a}^{-1}\right)$ releases latent heat at the rate of about $216 \mathrm{MJ} \mathrm{m}^{-2} \mathrm{a}^{-1}$ Above this altitude the firn is colder (Figure 5), which suggests that insufficient water is available to fully warm the firn. Near the firn line $(2100 \mathrm{~m})$, the temperature effect is smaller, about $6^{\circ} \mathrm{C}$, due to decreased infiltration of water because of the reduced vertical permeability caused by previous years' internal accumulations.

The thermal effect in the ablation area of glaciers is due to advection of "warmed" firn into the ablation area and, in the case of temperate glaciers, freezing of 
small amounts of water included in the glacier ice. Additional heat is added to the ablation area of "cold" glaciers by the freezing of water in crevasses (Jarvis and Clarke 1974). At McCall Glacier, the temperature deviation in the ablation area is about $2^{\circ} \mathrm{C}$. Figure 5 shows the extreme inversion of $10 \mathrm{~m}$ temperatures in the McCall Glacier, where the accumulation area is warmer than the ablation area.

In the Alaska Range, the $\overline{\mathrm{T}}_{\mathrm{a}}(1968-1982)$ is $-4.5^{\circ} \mathrm{C}$ at $1480 \mathrm{~m}$ altitude. At both Black Rapids Glacier (Harrison and others 1975) and Gulkana Glacier the firn temperature at $10 \mathrm{~m}$ is $0^{\circ} \mathrm{C}$, which is 6 to $8^{\circ} \mathrm{C}$ higher than the $\overline{\mathrm{T}}_{\mathrm{a}}$ at that altitude (Figure 5 ). The heat energy delivered to the firn by $b_{a}(k)$ is between $50-90$ MJ m $\mathrm{a}^{-1}$; about $30 \%$ of the rate at McCall Glacier. In the ablation area, the ice temperature is -0.5 to $-1.0^{\circ} \mathrm{C}$, which is 2 to $4^{\circ} \mathrm{C}$ higher than $\overline{\mathrm{T}}_{\mathrm{a}}$. This is a slightly larger temperature deviation than was found on the McCall Glacier, which may be explained by both the more rapid advection of firn into the ablation area and by the presence of water within the emergent ice which releases latent heat as it freezes.

Figure 2 shows that on glaciers in Alaska, when the snow-firn interface temperatures are above $-15^{\circ} \mathrm{C}$ the winter cold wave is completely removed each year and the bulk of the glacier is temperate. If the snow-firn interface temperature is much lower than $-15^{\circ} \mathrm{C}$ it is likely (due to the limited free water) that some cold firn will survive the melt season and be advected into the glacier. The lowest occurrence of cold firn will be just above the point of maximum internal accumulation (Figure 3), which is also where the maximum thermal effect occurs.

In the Alaska Range, glaciers are temperate (at $0^{\circ} \mathrm{C}$ except for the surface) up to about $2300 \mathrm{~m}$ altitude and are surrounded by permafrost. This situation is the result of the latent heat released by internal accumulation within the glaciers. We expect that temperate glaciers in permafrost areas are common in glacierized regions worldwide.

\section{EFFECTS ON RUNOFF}

The effects of internal accumulation on runof $f$ are (1) to increase the time delay between the beginning of snow ablation and runoff, and (2) to reduce the amount of runoff from what might otherwise be expected.

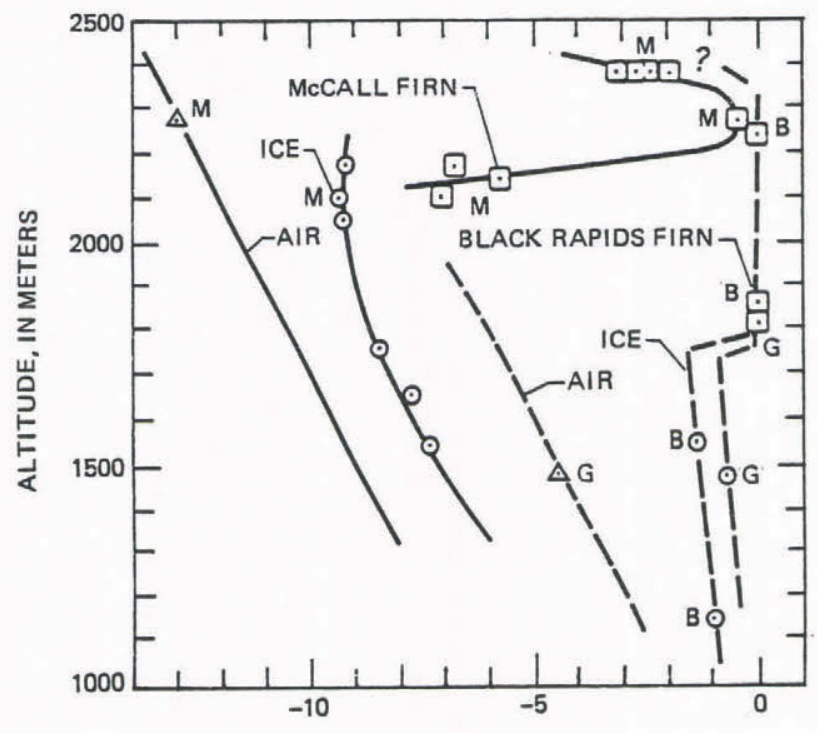

TEMPERATURE IN DEGREES CELSIUS

Fig.5. Firn $\square$ and ice $\odot$ temperatures at $10 \mathrm{~m}$ depth in McCall Glacier (Trabant and others 1975). Black Rapids Glacier (Harrison and others 1975), and Gulkana Glacier. Mean annual air temperature at McCall Glacier (Wendler and others 1974) and at Gulkana Glacier. The mean annual lapse rate for interior Alaska is from Haugen (unpublished) $b_{a}(k)$, IN METERS PER YEAR

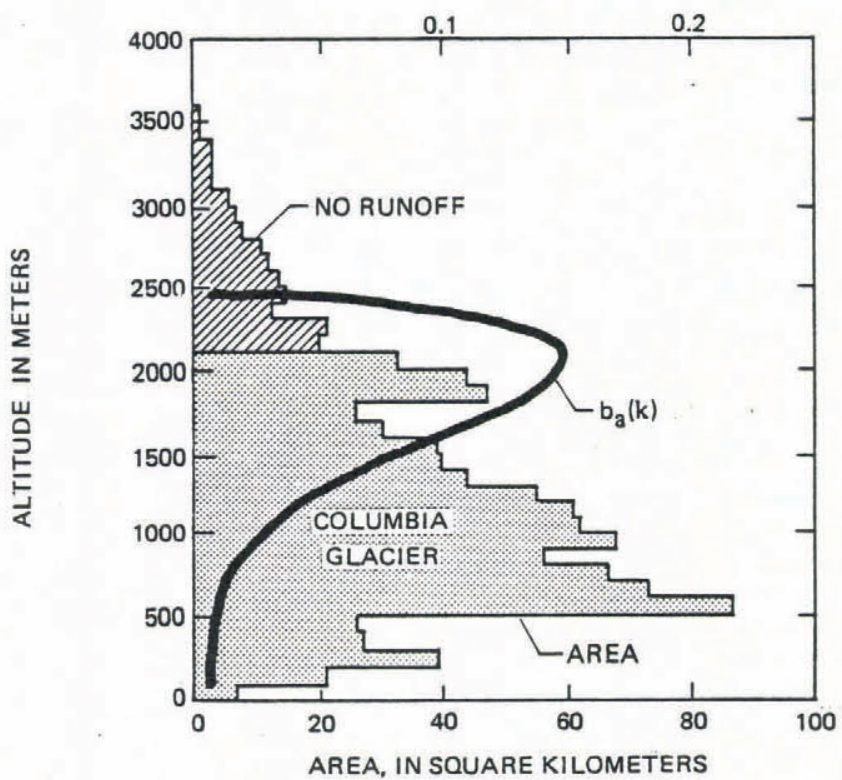

Fig.6. Internal accumulation on Columbia Glacier with the area altitude distribution and the area which does not contribute to runoff delimited.

The time delay between the start of surface ablation and runoff from snow is well known (Colbeck 1974). In the accumulation areas of glaciers, the same process further delays runoff through the porous firn where $b_{a}(k)$ is formed. In the Alaska Range, $b_{a}(k)$ alone can delay the entry of water into the englacial conduit system from two to four weeks when the average rate of production of water at the surface is $0.01 \mathrm{~m} \mathrm{~d}^{-1}$.

Runoff expected from surface melt and rainfall is reduced by the total amount of $b_{a}(k)$. For example, at altitudes above the zone of maximum development of internal accumulation (Figures 3 and 6 ) no runoff occurs in spite of measurable decreases in the mass of snow above the snow-firn interface; the apparent loss is entirely stored as internal accumulation, below the interface.

\section{IMPLICATIONS}

Internal accumulation is a process in which mass is redistributed from the surface to the interior of a glacier. It increases the mass balances of points in the accumulation areas of Alaska glaciers from 7 to $64 \%$ and accelerates the process of snow to ice conversion; for example, just above the equilibrium line on McCall Glacier, there is less than $1 \mathrm{~m}$ of porous firn over "impermeable" iced firn (Wakahama and others 1976).

Superimposed ice and internal accumulation are formed by essentially the same process and should be considered a continuum. The difference is that superimposed ice is deposited on and above the summer surface and $b_{a}(k)$, below.

The north to south gradient of both quantity and effects of internal accumulation is strong in Alaska but different from the results reported by Bazhev (1973) for Russia. The main difference is that Bazhev included mass redistribution within the snow increment, and we do not; therefore, for example, at lower latitudes where relatively greater thicknesses of snow trap more of the percolating water than is trapped in the thin snow on glaciers in high latitudes, the amount of internal accumulation recognized by Bazhev is greater than we report. Furthermore, large accumulation increments decrease the influence of winter cooling on the firn, further reducing the potential for $b_{a}(k)$ as defined herein.

Internal accumulation and its effects are to be expected at all latitudes and altitudes where there are negative temperatures in the firn and water penetration 
into the firn. The process may be primarily a single cycle, as in Alaska, or multiple cycles in warmer climates. Three cycles of freezing and rewetting of firn were reported by LaChapell (1961) for a single winter on the Blue Glacier $\left(48^{\circ} \mathrm{N}\right.$ latitude on the north-western coast of Washington State, USA). The three cycles of firn warming were due to mid-winter rain storms. We estimate from $0.20-0.30 \mathrm{~m}$ of $b_{a}(k)$ was formed at 2050 $m$ altitude on the Blue Glacier in 1957-58, using LaChapelle's data. An important conclusion is that internal accumulation occurs in temperate glaciers in strongly maritime climates as well as in glaciers in cold continental climates. This considerably extends the range of influence of internal accumulation.

\section{ACKNOWLEDGEMENTS}

The work on McCall Glacier was supported by Atmospheric Sciences Section, National Science Foundation Grants GA-10090, GA-28278x, and GA-37306, and colleagues at the University of Alaska. Studies at other glaciers in Alaska were supported by the US Geological Survey.

\section{REFERENCES}

Ahlmann H W 1948 Glaciological research on the North Atlantic coasts. Royal Geographical Society Research Series no 1.

Bazhev A B 1973 Infiltrationand run-off of melt water on glaciers. International Association of Hydrological Sciences Publication 95 (Symposium on the hydrology of glaciers): $245-250$

Benson C S 1959 Physical investigations on the snow and firn of northwest Greenland 1952, 1953, and 1954. US Snow Ice and Permafrost Research Establishment. Research Report 26

Benson C S 1962 Stratigraphic studies in the snow and firn of the Greenland Ice Sheet. US Snow Ice and Permafrost Research Establishment. Research Report 70

Colbeck S C 1974 The capillary effects on water percolation in homogeneous snow. Journal of Glaciology 13(67): $85-98$

Harrison W D, Mayo L R, Trabant D C 1975 Temperature measurements on Black Rapids Glacier, Alaska, 1973. In Weller $\mathrm{G}$ and Bowling S A (eds) Climate of the Arctic. Geophysical Institute, University of Alaska; 350-352

Hughes T P, Seligman G 1939 The temperature, melt water movement and density increase in the neve of an alpine glacier. Royal Astronomical Society, Geophysical supplement, Monthly Notices 4(9): 616-647

Jarvis G T, Clarke G K C 1974 Thermal effects of crevassing on Steele Glacier, Yukon Territory, Canada. Journal of Glaciology 13(68): 243-254

LaChapelle E 1961 Energy exchange measurements on the Blue Glacier. International Association of Scientific Hydrology 54: 302-310

Liest $\varnothing 1$ O 1967 Storbreen Glacier in Jotunheimen, Norway. Norsk Polarinstitutt Skrifter 141: 3-63

Mayo L R, Meier M F, Tangborn W V 1972 A system to combine stratigraphic and annual mass-balance systems: a contribution to the International Hydrological Decade. Journal of Glaciology 11(61): 3-14

Messel S 1971 Mass and heat balance of Omnsbreen a climatically dead glacier in southern Norway. Norsk Polarnstitutt Skrifter 156: 3-43

Muller Fritz 1962 Zonation in the accumulation area of the glaciers of Axel Heiberg Island, NWT, Canada. Journal of Glaciology 4(33): 302-311

Paterson W S B 1981 The physics of glaciers. Second edition. Pergamon Press. 380p

Trabant D C, Harrison W D, Benson C 1975 Thermal regime of McCall Glacier, Brooks Range, northern Alaska. In Weller $\mathrm{G}$ and Bowling $\mathrm{S}$ A (eds) Climate of the Arctic. University of Alaska: $347-349$

Wakahama G, Kuroiwa D, Hasemi T, Benson C S 1976 Field observations and experimental and theoretical studies on the superimposed ice of McCall Glacier, Alaska. Journal of Glaciology 16(74): 135-149
Wendler G, Benson C, Fahl C, Ishikawa N, Trabant D, Weller G 1975 Glacio-meteorological studies of McCall Glacier. In Weller $\mathrm{G}$ and Bowling $\mathrm{S} \mathrm{A}$ (eds) Climate of the Arctic. University of Alaska: 334-338

Wendler G, Ishikawa N, Streten N 1974 The climate of the McCall Glacier, Brooks Range, Alaska, in relation to its geographical setting. Arctic and Alpine Research 6(3): $307-318$ 